\title{
Erratum
}

\section{The Diffusion of International Norms: Why Identity Matters}

\author{
Amy Gurowitz
}

International Politics (2007) 44, 484. doi:10.1057/palgrave.ip.8800193

Correction to: International Politics (2007) 43, 305-341.

doi: $10.1057 /$ palgrave.ip. 8800145

In Table 1 the italics were omitted from the published version. The correct table is reproduced below.

The 1996 Katzenstein reference that has been listed as Katzenstein, P.J., ed. (1996c) has been published incorrectly. The correct version is reproduced below:

Katzenstein, P.J., (ed.) (1996) The Culture of National Security: Norms and Identity in World Politics, New York: Columbia University Press.

We would like to apologize for any inconvenience these errors might have caused.

Table 1 The relationship between international identity and identity security ${ }^{\mathrm{a}}$

\begin{tabular}{lll}
\hline $\begin{array}{l}\text { Strength of international } \\
\text { identity }\end{array}$ & \multicolumn{2}{c}{ Identity security } \\
\cline { 2 - 3 } Strong & Insecure & Secure \\
\hline Medium & $\begin{array}{l}\text { Germany early post-war } \\
\text { Former Eastern Bloc states } \\
\text { (Type 1 states) }\end{array}$ & $\begin{array}{l}\text { Germany today } \\
\text { Canada } \\
\text { (Type 2 states) }\end{array}$ \\
Weak & $\begin{array}{l}\text { Japan today } \\
\text { (Type 3 states) }\end{array}$ & $\begin{array}{l}\text { United States } \\
\text { (Type 4 states) }\end{array}$ \\
Japan early post-war period \\
(Type 5 states)
\end{tabular}

${ }^{\text {a }}$ States listed in italics are hypothesized as to where they fit. Other states have been studied in some detail in this regard (See Gurowitz, 2001 on Canada and 2000 on Malaysia). 